\title{
The End of the ANC Era: An Analysis of Corruption and Inequality in South Africa \\ Olivia Lannegren ${ }^{1} \&$ Hiroshi Ito ${ }^{2}$ \\ ${ }^{1}$ Department of International Business, Uppsala University, Stockholm, Sweden \\ ${ }^{2}$ Faculty of Economics, Nagoya University of Commerce and Business, Nisshin, Japan \\ Correspondence: Hiroshi Ito, Faculty of Economics, Nagoya University of Commerce and Business, Nisshin, Aichi, Japan. Tel: 81-561-73-2111. E-mail: hito@nucba.ac.jp
}

Received: February 24, 2017

doi:10.5539/jpl.v10n4p55
Accepted: July 19, $2017 \quad$ Online Published: August 30, 2017

URL: https://doi.org/10.5539/jpl.v10n4p55

\begin{abstract}
The 2016 municipality election of South Africa was received as a shocking event. Despite a strong belief that the ANC would always rule in South Africa, the African National Congress (ANC), which has been governing the country since the end of apartheid in 1994, received the worst results ever recorded. The ANC with president Jacob Zuma received 54 percent of the votes, which is a considerable decrease from 62 percent in 2011. This election was a clear sign that the ANC is in trouble towards the 2019 elections. The party seriously needs to rethink its strategies and investigates why the votes are decreasing. Given South Africa being a key player in global governance and in particular a strong leader among the African countries, it is significant to understand this political turmoil, as it may influence the political directions of other countries in that area. With reviews of relevant literature, therefore, this paper analyzes the current political situation in South Africa, focusing on corruption and inequality. The paper suggests connections between corruption, Jacob Zuma, and the potential end of the ANC era. The issues of inequality describes more the difficult situation that South Africans are facing and can be connected to the desire for change. It would be interesting to further analyze whether South Africa would be ready for a multiparty democracy with a peaceful transition of power after the national elections in 2019.
\end{abstract}

Keywords: South Africa, municipality election, African National Congress

\section{Introduction}

In August 2016, the municipality election, in which a record high number of 26 million of a total population of 53 million voted, was held in South Africa. The African National Congress (ANC), which has been governing the country since the end of apartheid in 1994, received the worst results ever recorded. The ANC with president Jacob Zuma received 54 percent of the votes, which is a considerable decrease from 62 percent in 2011 (Bennet, 2016). The defeat of Nelson Mandela Bay (former Port Elizabeth), the municipality that has great historical significance for the ANC due to its Nelson Mandela's origin, was surprising. The loss of the two important economic cities Johannesburg and Pretoria was also a notable defeat for the ANC. The party has lost control over 27 of the municipalities, including four of the countries' eight main cities.

Since 1994, there has been a strong belief that the ANC would always rule in South Africa. This belief can be shown by Jacob Zuma's statement in 2004: " the ANC party would rule South Africa until Jesus comes back" (Gevisser, 2016, p.1). However, the 2016 result and even results dating back to the 2011 elections suggest the decrease in votes, a sign that the ANC was likely to lose power (Chipkin, 2016).

The ANC has been known as the revolutionary force that helped end the apartheid regime. The support for the ANC from the voters has always been clear that South Africa has been considered a one party nation (Chipkin, 2016). The ANC has been more than a political party; it has been a symbol and proudness of black power, unity and equality. Also, Nelson Mandela, the first elected black president of the state, who is often described as the "Father of the Nation", is the symbol of strength, equality, peace and forgiveness for the ANC. Because the ANC plays an important role in history and is a nationalistic pride for many South Africans, it is a drastic change for South Africa that this support is on the downfall and that new parties are emerging (Raghayan, 2013).

The results of the elections suggest that the South Africans have had a change in mind. The Democratic Alliance (DA), the largest opponent party, received 26 percent of the votes, which turned out to be its best election ever. 
The DA is led by a 36-year-old Mmusi Maimane and its main political point has been fighting corruption. The DA is originally a white party, and thus there is symbolic change in Mmusi Maimane being black. The radically left Economic Freedom Fighters party, only being three years old, received eight percent of the votes. It pledged the nationalization of mines and redistributing lands from the current white owners to the black South Africans and also fighting corruption (Gevisser, 2016).

This election was a clear sign that the ANC is in trouble towards the 2019 elections. The party seriously needs to rethink its strategies and investigates why the votes are decreasing. This situation, given South Africa being a key player in global governance and a strong leader among the African countries, is significant. South Africa has many deep-rooted issues that result in a large unsatisfaction among the population. The two principal issues that South Africa faces today are corruption and inequality, which may be why South Africans are asking for change (Raghavan, 2013). Various studies have been done on these issues but few directly connect these issues with the current political situation (Gumeda, 2008; Lodge, 2002; Spaull, 2013; Piketty, 2014).

The purpose of this paper is therefore to understand the current political situation in South Africa, focusing on corruption and inequality.

\section{Literature Review}

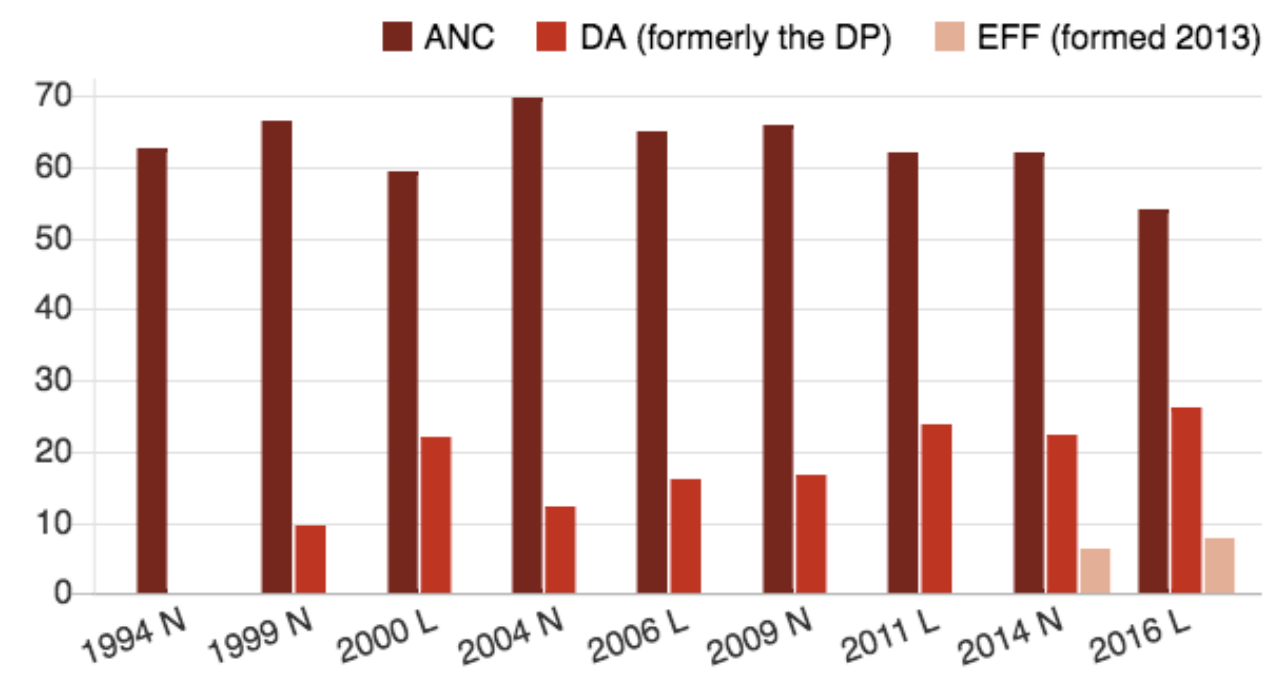

Source: SA electoral commission for national elections $(\mathrm{N})$ and local elections $(\mathrm{L})$ - excludes $\quad \mathrm{B} / \mathrm{B} / \mathrm{C}$ $1995 / 1996$ local results

Figure 1. National and local election results in South Africa (BBC, 2016)

Figure 1 shows that the decrease in ANC votes and especially the increase in DA votes in the local 2011 election. Although the decreasing support is not an entirely new issue for the ANC, it was only after the 2014 elections that scholars started debating the ANCs potential decline in power (Chipkin, 2016). In the following sections, we will explore potential reasons for the ANC's decline in votes: corruption and inequality in South Africa.

\subsection{Corruption}

Corruption for South Africans has become a normal everyday occurrence. In almost every year there has been a scandal of high-appointed politicians being corrupt. In 1998 a survey was conducted where 55 percent of the population answered that they thought that civil servants took bribes (Lodge, 2002). In 2011, Willie Hofmeyer, the former head of the Special Investigation Unit, reported that 25-30 billion South African rand (equivalent to 2-2,4 billion USD) was lost to government procurement budget each year due to fraud. South Africans are rating corruption as one of the most important issues within the public sector. South Africans are increasingly seeing their country as corrupt and valuing corruption as an important issue. Indeed, according to the South African Social Attitude Survey, between the period of 2001-2006, the number of people considering that corruption should be a national priority doubled (Newham, 2014).

According to Lodge (2002), the reason for the high corruption rates is the inherited style of governing from the party prior to 1994 during the apartheid regime. Dullah Omar, a former Minister of Justice(1994-2004), claimed that there has been an increase in corruption even after 1994 (Lodge, 2002). 
Jacob Zuma, who took presidency in 2009, has been part of many corruption scandals dating back to 1995 . In 2008, he was accused of a number of allegations including: racketeering, money laundering and fraud (Gumede, 2008). The scandal that has made the biggest impact on South Africans occurred in March 2016. The highest court in South Africa ruled that Zuma violated the constitution when failing to repay the government for money used to upgrade his luxury residence. Most recently in October 2016, he was accused of being influenced by the powerful and wealthy Gupta family when letting go one of his ministers. However, he has never been convicted of any of these allegations (Bennet, 2016).

\subsection{Jacob Zuma}

Many scholars and foreign journalists have argued that the problem of the decrease in votes has a connection to Jacob Zuma (Ibid). A survey conducted in 2015 showed that the president's popularity is on the decline from 6.1 in 2009 to 5.2 in 2015 where 10 means totally in favor and 0 means totally against (Ipsos, 2015). Besides, the current president was the above-stated corruption scandals sent to court in 2006 when he was accused for raping a close family friend who was half his age (Gumede, 2008). Again, he was freed from this allegation. During Nelson Mandela's funeral in 2015, he was booed by hundreds of people in the arena in front of many world leaders, including Barack Obama (Cohen \& Wild, 2013).

On the other hand, when Zuma was elected he was seen as arguably the most popular politician in South Africa since Nelson Mandela. For instance groups of women stood outside the court during his rape-trial burning the picture of the girl in question. Many believed that Zuma would be a positive change from Thabo Mbeki that had a growing discontent during the end of his presidency, and would come as the savior of the rural poor, the uneducated youth and black middle-class. Zuma has been praised for his communication skills to the voters and his traditional views. He has a deep connection to his traditional background from Kwazulu Natal showing this by often wearing animal skins and living in polygamy with seven wives and 21 children (Hunter, 2011).

\subsection{Inequality}

When the apartheid ended in 1994 and Nelson Mandela became president, was assumed that inequality would positively change for the oppressed black South Africans. Mandela was very symbolic and shared his dreams of equality that the population believed in (Raghavan, 2013). More than two decades later, this dream has not come true, with 60-65 percent of South Africa's wealth being concentrated in just 10 percent of the population (Piketty 2014).

Thomas Piketty even argues that income inequality is even higher today than two decades ago. The majority of blacks live in poverty without the access to electricity, proper housing or clean water. The same whites and small black elite companies and families that have been powerful for decades, still to this day control to a large content, the economy. For instance unemployment in 2014 was at 25 percent and white people in average received wages six times as higher as their black counterparts. In South Africa whites account for 8.1 percent of the total population and at the same time in the economically top five percent of the nation up to 80 percent are white (Simon, 2011). Even the trade unions that historically have backed the ANC now started protesting due to the lacking existence of salary increases (Cowell, 2014).

\section{Discussion}

Studies show that South Africans are increasingly caring about corruption and knowledgeable of its increase. Since both of ANCs opposition parties, the DA and EFF, had fighting corruption as election policies this could be a sign that it is corruption South Africans believe the ANC has a big problem with. By not voting for the ANC the people can be showing that they are well aware of the extent that corruption is taking place within the ANC and that now is the time to say enough is enough. The 2016 elections showed that ANC had their strongest support in rural areas and this might be because news of the latest corruption might not have reach them to the same extent as in urban areas.

There is also a clear connection that Jacob Zuma has not delivered enough or met the expectations in his seven years as president. Many South Africans might initially have had faith in him to be a positive change from Thabo Mbeki but statistics show that this did not consist. Even though Zuma has been liked as a person, his involvement in a series of corruption and other incidents has shown to be a deal breaker. As has been explained, South Africans have had to deal with corruption throughout time. The difference now can firstly be that they are finally tired of it and fighting for it to stop and secondly that the corruption is now coming directly from their top leader, the president and it is in now 'personal' corruption. The corruption that Zuma has been accused for is in the form of money put on his private life and not to do with political deals like Mbeki and the firearm deal. This type of corruption clearly demonstrated the difference between the power of the small elite and the poor 
oppressed majority as the others. Zuma was the person who was supposed to help the poor blacks and bring up the middle class and not make himself a more wealthy man. This type of corruption did not happen or at least was not reported of with Nelson Mandela or Thabo Mbeki and this might explain the change.

Although ANC has had more than two decades to change and eliminate inequality since 1994, the inequality still persists. This could be a big part of ANCs downfall. The alarming news is a possible increase in inequality, which has made South Africans seek changes. Also, Nelson Mandela's death in 2014 can be another reason for South Africans to give up on ANC since their symbol of hope and equality might have died with him and also meant the loss of the symbol for the ANC.

What does the ANC need not to continue losing power and risk losing the presidential elections in 2019? It is clear that they have to do something; otherwise the support for the DA and the EFF will just continue to grow. It is also apparent that they have gotten comfortable due to the lack of competition and the perception of the great, unstoppable ANC. The new generation of voters born after 1994 does not have the historical bonds to the movement that freed them from the apartheid and therefore feels free to vote on other parties. The 2016 elections were not the first warning sign. Already after the 2011 local elections, the ANC should have started taking measures for change. ANC has relied on history of fighting the apartheid, symbolism and important leaders, especially Nelson Mandela.

This paper argues that there is a connection between the weakened status of the ANC and Jacob Zuma. A first step would therefore be to as soon as possible get him to resign. This would show the South African people that the party has taken the situation seriously and are listening to the people's concerns and therefore want to work on changes. This would also show that the ANC opposes corruption. The ANC should also acknowledge that their biggest competitor has a young 36 year old as their leader and that this could be a working strategy. ANC should therefore also appoint a younger leader that is not already nested in old ties that could be perceived as already corrupt.

Second, the ANC has to find a way to create the same hope that was created in 1994 for change that they later lost. This connects with the need for a serious reformation of South Africa. Corruption and inequality show legacy from the apartheid regime and ANC needs to find a way to totally change how the country is governed and show the people that they are serious with this change. The ANC has a deeply routed relationship with the South African people and this is not completely lost yet just because many choose not to vote for them. The ANC just needs to win back trust and demonstrates that it is willing to fight again. Soon, naturally with an ageing population, the people who witnessed the apartheid and established a deep relationship with the ANC will be replaced with a population who does not have the same relationship and just see the great issues that South Africa is facing.

However, the oppositional parties the DA and EFF are at this point not clear winners either. DA having a history being white can be a big problem in collecting some South Africans votes even with a black leader since this symbolizes the white regaining power. Also the EFF is still considered very radical.

In the end, the current situation can be arguably very positive for South Africa and a good step in its democratization. The decrease of ANC voters allows more space for other parties to fuel each other in competition to be better voices for the population and mirror all views of South Africans.

\section{Conclusion}

The paper suggests connections between corruption, Jacob Zuma, and the potential end of the ANC era. The issues of inequality describes more the difficult situation that South Africans are facing and can be connected to the desire for change. It would be interesting to further analyze whether South Africa would be ready for a multiparty democracy with a peaceful transition of power after the national elections in 2019. This waits to see, as the governing of the municipalities that were changed in the local municipality election in august will prove that.

\section{Acknowledgments}

We thank Mr. Ezra Anton Greene for editing this paper.

\section{References}

BBC. (2016). South Africa local elections: ANC suffers major setback. BBC News. Retrieved from http://www.bbc.com/news/world-africa-36985339

Bennet, J. (2016). A Vote for Change in South Africa. The New York Times. Retrieved from https://www.nytimes.com/2016/08/08/opinion/a-vote-for-change-in-south-africa.html?_r=0 
Chipkin, I. (2016). The Decline of African Nationalism and the State of South Africa. Journal of Southern African Studies, 42(2), 215-227. https://doi.org/10.1080/03057070.2016.1143208

Cohen, M., \& Wild, F. (2013). South African President Jacob Zuma Booed at Mandela Memorial. Bloomberg. Retrieved from https://www.bloomberg.com/news/articles/2013-12-10/south-african-president-zuma-booed-at-mandela-me morial-service

Cowell, T. (2014). South African Union Breaks From ANC as Alliance Frays further. The New York Times. Retrieved from https://www.nytimes.com/2014/05/09/world/africa/south-african-vote.html

Gevisser, M. (2016, August 9). A Seismic Shock for Jacob Zuma. The New York Times. Retrieved from https://www.nytimes.com/2016/08/10/opinion/a-seismic-shock-for-jacob-zuma.html

Gumede, W. M. (2008). South Africa: Jacob Zuma and the Difficulties of Consolidating South Africa's Democracy. African Affairs, 107, 261-271. https://doi.org/10.1093/afraf/adn018

Hunter, M. (2011). Beneath the "Zunami”: Jacob Zuma and the Gendered Politics of Social Reproduction in South Africa. Antipode, 43(4), 1102-1126. https://doi.org/10.1111/j.1467-8330.2010.00847.x

Ipsos. (2015). Denting Jacob Zuma's Popularity and Reputation. Retrieved from www.ipsos.co.za

Lodge, T. (2002). Political Corruption in South Africa: From Apartheid to Multiracial State. In A. Heidenheimer, \& M. Johnson (Eds.), Political Corruption: Concepts and Contexts (pp. 403-424). New Brunswick, NJ.

Manyaka, R. K., \& Nkuna, N. W. (2014). The Phenomenon of Corruption in the South African Public Sector: Challenges and Opportunities. Mediterranean Journal of Social Sciences, 5(27), 1572-1580. https://doi.org/10.5901/mjss.2014.v5n27p1572

Newham, G. (2014). Why Is Corruption Getting Worse In South Africa? Retrieved from www.corruptionwatch.org

Piketty, T. (2014). Capital in the Twenty-First Century. Cambridge, MA: The Belknap Press of Harvard University Press. https://doi.org/10.4159/9780674369542

Raghavan, S. (2013, December 6). South Africa still struggling to fulfill Mandela's hopes and dreams. The Washington Post. Retrieved from https://www.washingtonpost.com/world/africa/south-africa-still-struggling-to-fulfill-mandelas-hopes-and-dr eams/2013/12/06/95ce7a26-5e80-11e3-8d24-31c016b976b2_story.html

Simon, A. (2015). Black Economic Power has failed: Piketty on South African inequality. The Guardian. Retrieved

from https://www.theguardian.com/world/2015/oct/06/piketty-south-africa-inequality-nelson-mandela-lecture

\section{Copyrights}

Copyright for this article is retained by the author(s), with first publication rights granted to the journal.

This is an open-access article distributed under the terms and conditions of the Creative Commons Attribution license (http://creativecommons.org/licenses/by/4.0/). 